\title{
Prevalence of Brugada-type ECG pattern and early ventricular repolarization pattern in Tunisian athletes
}

This article was published in the following Dove Press journal:

Open Access Journal of Sports Medicine

16 April 201 I

Number of times this article has been viewed

\author{
Sana Ouali' \\ Helmi Ben Salem' \\ Sami Hammas' \\ Elyes Neffeti' \\ Fahmi Remedi' \\ Abdallah Mahdhaoui ${ }^{2}$ \\ Essia Boughzela' \\ Rafik Mankai ${ }^{3}$ \\ 'Department of Cardiology, Sahloul \\ Hospital, Sousse, Tunisia; ${ }^{2}$ Department \\ of Cardiology, Farhat Hached, Sousse, \\ Tunisia; ${ }^{3}$ Central Sports Medicine \\ Centre of El Menzah, Tunisia
}

\begin{abstract}
Introduction: No data regarding the prevalence of the Brugada-type electrocardiogram (ECG) pattern and the early ventricular repolarization pattern (ERP) in the North African population were available. The aims of this study were to determine the frequency of Brugada-type ECG pattern and ERP in Tunisia and to evaluate ECG descriptors of ventricular repolarization in a population of athletes.

Methods: Over a 2-year period, resting 12-lead ECG recordings were analyzed from athletes ( $\mathrm{n}=540 ; 348$ males; age $18.3 \pm 2.4$ years). Brugada-type ECG pattern was defined as Type 1 , 2, or 3, and ERP was characterized by an elevation of the J point in the inferior and/or lateral leads. The population was divided into three groups of athletes: ERP group; Brugada-type ECG pattern group; and control group, with neither ERP nor Brugada ECG pattern. Clinical and electrocardiographic parameters were compared among the study groups.

Results: Nine subjects (1.66\%) had a Brugada-type ECG pattern. None of them had the covedtype, $3(0.6 \%)$ had the Type 2, and $6(1.1 \%)$ had the Type 3 . All subjects were asymptomatic. A Brugada-type ECG pattern was observed in seven males. No female had the Type 2 Brugada ECG pattern. ECG parameters were similar among Brugada-type ECG pattern and control athletes. ERP (119 subjects, 22\%) was obtained in 98 males. Heart rate was lower, the QRS duration shorter and QT and $\mathrm{T}_{\text {peak }}-\mathrm{T}_{\text {end }}$ intervals were longer in ERP than control groups.

Conclusion: The results indicate that the frequency of the Brugada-type ECG pattern and ERP were respectively $1.66 \%$ and $22.00 \%$ in athletes, being more prevalent in males. The ERP group experienced shorter QRS duration and longer $\mathrm{T}_{\text {peak }}-\mathrm{T}_{\text {end }}$ interval than in the control population.
\end{abstract}

Keywords: J wave, ERP athletes, T wave

\section{Introduction}

The $\mathrm{J}$ wave is a deflection immediately following the QRS complex of the surface electrocardiogram (ECG). When partially buried in the $\mathrm{R}$ wave, the $\mathrm{J}$ wave appears as J-point elevation or ST-segment elevation. Renewed interest in early repolarization arose after the discovery of an associated high risk of sudden cardiac death by ventricular fibrillation with both ST elevation in right precordial (V1-V3) $)^{1,2}$ and early repolarization in the inferior or mid to lateral precordial leads. ${ }^{3-5}$

Conflicting evidence exists on prevalence and prognostic significance of the Brugada-type ECG pattern and early ventricular repolarization pattern (ERP), particularly when found by chance in an asymptomatic individual and in an ethnic population where epidemiological data are lacking. To our knowledge, no data regarding the prevalence of the Brugada-type ECG pattern and the ERP exist in the North African population.
Service de cardiologie, Hôpital Sahloul, Route Ceinture, Cité Sahloul 5054, Sousse, Tunisie

Tel +21673367446

$\mathrm{Fax}+21673367451$

Email sanaouali@hotmail.fr 
The aim of this study was to determine the frequencies of the Brugada-type ECG pattern and ERP and to evaluate ECG descriptors of ventricular repolarization in a population of Tunisian athletes.

\section{Methods}

\section{Subjects}

Over a 2-year period (2008-2009), resting 12-lead ECG recordings were analyzed from athletes $(n=540$; 348 males; $100 \%$ white Arabs, aged $18.3 \pm 2.4$ years, height $=172 \pm 12 \mathrm{~cm}$, weight $=63.6 \pm 12.3 \mathrm{~kg}$ ) as part of their physical examination. They were routinely controlled in the Central Sports Medicine Centre of El Menzah in Tunisia. The studied athletes represented 14 disciplines. All those who entered this study had no evidence of organic heart disease as judged from clinical history and physical and echocardiographic examination.

A 12-lead ECG (at a paper speed of $25 \mathrm{~mm} / \mathrm{s}$ and $1 \mathrm{mV} / 10 \mathrm{~mm}$ standard gain) was recorded from each subject with the same equipment by the same person.

Brugada-type ECG pattern was defined as Type 1, 2, or 3. The consensus report of the Study Group of the Molecular Basis of Arrhythmias laid down precise diagnostic criteria for the Brugada-type ECG pattern, ${ }^{6,7}$ recognizing three variants of the repolarization pattern in chest leads V1-V3 (Type 1, classical convex ST elevation of $\geq 2 \mathrm{~mm}$; Type 2 , J wave amplitude $\geq 2 \mathrm{~mm}$ with concave ST elevation $\geq 1 \mathrm{~mm}$; and Type 3, J point elevation with the ST segment isoelectric or elevated by $<1 \mathrm{~mm}$ ).

ERP was defined as elevation of the $\mathrm{J}$ point (QRS-ST junction) noted as either QRS slurring or notching $\geq 0.1 \mathrm{mV}$ in more than two adjacent leads in the inferior leads (II, III, and $\mathrm{aVF}$ ) and/or lateral leads ( $\mathrm{I}, \mathrm{aVL}$, and $\mathrm{V}_{4}$ through $\left.\mathrm{V}_{6}\right){ }^{3}$

PR intervals, $\mathrm{P}$ wave duration and amplitude, $\mathrm{T}$ wave amplitude, and QRS amplitude were measured on lead II. $\mathrm{P}$ wave, $\mathrm{T}$ wave and QRS axis were calculated from frontal leads. The maximum QRS duration was assessed in any of the measurable leads of each ECG. Mean RR interval was also measured.

The interval from the peak to the end of the $\mathrm{T}$ wave $\left(\mathrm{T}_{\text {peak }}-\mathrm{T}_{\text {end }}\right)$ and the QT interval were measured on leads V2 or V3 and leads II or V5. The point of T wave offset was defined as the return to the baseline. $\mathrm{T}_{\text {peak }}-\mathrm{T}_{\text {end }} / \mathrm{QT}$ ratio was also calculated.

QT intervals were corrected for heart rate using Fridericia's $\left[\mathrm{QTc}\right.$ Fri $\left.=\mathrm{QT}(\mathrm{RR})^{-1 / 3}\right]$ and Sagie-Framingham's $[\mathrm{QTcFr}=\mathrm{QT}+0.154(1000-\mathrm{RR})]$ formulas. ${ }^{8,9}$
All ECG measurements were performed separately by two independent investigators who were blinded to the clinical data of the patients. The interpreters of the ECGs assessed also Brugada-type ECG patterns and ERP simultaneously. The averages of the measurements of the two observers were used for comparisons. The diagnosis of Brugada-type ECG pattern or ERP was made only when both investigators agreed on the classification of the ECG abnormalities.

The population was subsequently divided into three groups: ERP group; Brugada-type ECG pattern group; and control subjects, without either ERP or Brugada type ECG pattern. Clinical and ECG parameters were described for each group and compared with control groups.

\section{Statistical analysis}

The age, gender, and ECG findings of the cases were recorded with SPSS (version 12.0, SPSS, Inc, Chicago, IL). Values are expressed as the mean $\pm \mathrm{SD}$ (standard deviation), $\mathrm{n}$ value, and percentage (\%). Student's $t$-test for independent samples and the chi-squared test were used, when appropriate, comparing two different groups. Two-sided $P<0.05$ was considered significant. The study protocol was approved by the Ethics Committee of the Central Sports Medicine Centre of El Menzah in Tunisia.

\section{Results}

\section{Prevalence of the Brugada-type ECG pattern}

Among 540 athletes, we found nine subjects (1.66\%) with a Brugada-type ECG pattern. All the subjects with the Brugada-type ECG pattern had a saddleback-type ECG abnormality and were asymptomatic. Three $(0.6 \%)$ had the Type 2 (Figure 1), and six (1.1\%) had the Type 3. A Brugada-type ECG pattern was obtained in two females and in seven males. No female had the Type 2, and none of the athletes displayed both ERP and Brugada-type ECG pattern.

The mean age, mean body area, and mean systemic arterial pressure in Brugada-type ECG pattern athletes were respectively $19.3 \pm 1.0$ years, $1.77 \pm 0.16 \mathrm{~m}^{2}$, and $120 \pm 18 / 74 \pm 9 \mathrm{mmHg}$, that were similar to clinical control parameters. However, males are more prevalent in Brugada-type ECG pattern than control athletes $(77.7 \%$ versus $58.9 \%$; $P<0.0001)$. Mean ECG parameters are summarized in Table 1. Heart rate, PR interval, $P$ wave duration and amplitude, $\mathrm{T}$ wave, $\mathrm{P}$ wave, QRS axis, QRS duration, 


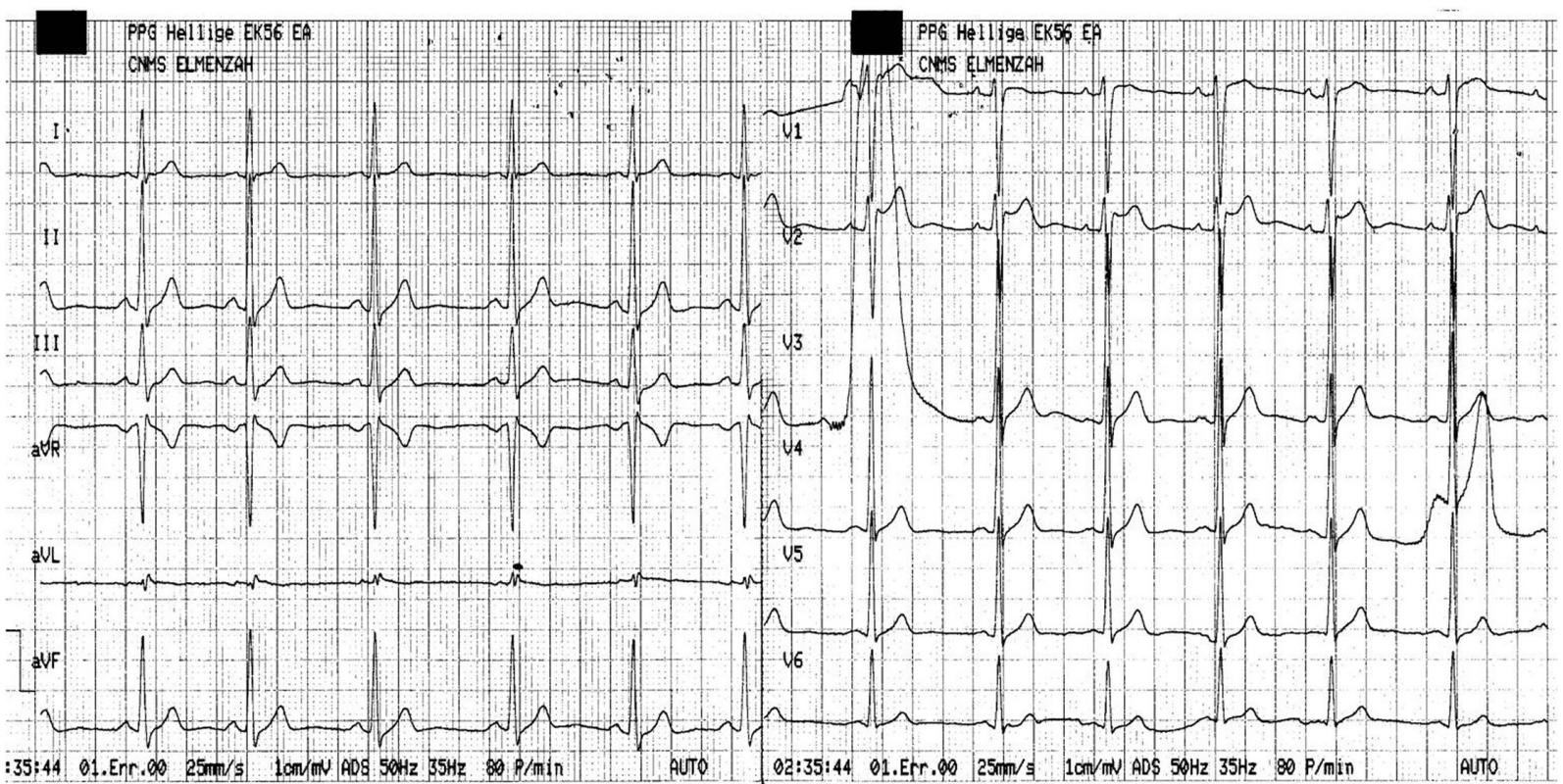

Figure I Type 2 Brugada-type ECG of an athlete demonstrates saddle-back type ST-segment elevation ( $>$ I mm) in lead V2.

Table I Clinical and ECG parameters of study cohorts

\begin{tabular}{|c|c|c|c|c|}
\hline Parameter & ERP group & Control group & $\begin{array}{l}\text { Brugada-type } \\
\text { ECG pattern group }\end{array}$ & $P^{a}$ \\
\hline N (\%) & 119 (22\%) & $412(76.3 \%)$ & $9(1.7 \%)$ & \\
\hline Male gender (N, \%) & $98,82.3 \%$ & $243,58.9 \%$ & $7,77.7 \%$ & 0.000 \\
\hline Age (years) & $18.2 \pm 2.3$ & $18.1 \pm 2.9$ & $19.3 \pm 1$ & 0.6 \\
\hline Body area $\left(\mathrm{m}^{2}\right)$ & $1.78 \pm 0.23$ & $1.72 \pm 0.19$ & $1.77 \pm 0.16$ & 0.009 \\
\hline Weight (kg) & $66.7 \pm 12.4$ & $62.7 \pm 12.1$ & $65 \pm 9.9$ & 0.002 \\
\hline Height $(\mathrm{cm})$ & $172.7 \pm 19$ & $17 \mid .6 \pm 9$ & $174.1 \pm 7.9$ & 0.375 \\
\hline Systolic BP (mmHg) & $116 \pm 12$ & $115 \pm 11$ & $120 \pm 18$ & 0.81 \\
\hline Diastolic BP (mmHg) & $70 \pm 9$ & $68 \pm 10$ & $74 \pm 9$ & 0.136 \\
\hline $\mathrm{RR}(\mathrm{ms})$ & $867 \pm 157$ & $781 \pm 145$ & $815 \pm 218$ & 0.000 \\
\hline PR interval (ms) & $143 \pm 16$ & $|43 \pm 2|$ & $145 \pm 13$ & 0.76 \\
\hline QRS interval (ms) & $86 \pm 10$ & $89 \pm 11$ & $90 \pm 13$ & 0.005 \\
\hline QRS axis $\left(^{\circ}\right)$ & $68 \pm 25$ & $67 \pm 27$ & $58 \pm 26$ & 0.9 \\
\hline T axis $\left({ }^{\circ}\right)$ & $58 \pm 18$ & $55 \pm 20$ & $56 \pm 7.5$ & 0.19 \\
\hline $\mathrm{P}$ axis $\left({ }^{\circ}\right)$ & $56 \pm 25$ & $56 \pm 26$ & $65 \pm 10$ & 0.97 \\
\hline $\mathrm{P}$ wave duration (ms) & $94 \pm 12$ & $94 \pm 12$ & $98 \pm 10$ & 0.8 \\
\hline QRS amplitude DII (mV) & $1.6 \pm 0.4$ & $\mathrm{I} .4 \pm 0.4$ & $\mathrm{I} .4 \pm 0.7$ & 0.000 \\
\hline P wave amplitude DII (mV) & $0.14 \pm 0.05$ & $0.15 \pm 0.05$ & 0.160 .04 & 0.2 \\
\hline T wave amplitude DII (mV) & $0.48 \pm 0.17$ & $0.39 \pm 0.18$ & $0.32 \pm 0.11$ & 0.000 \\
\hline QT interval DII or V5 (ms) & $389 \pm 48$ & $370 \pm 27$ & $366 \pm 40$ & 0.000 \\
\hline QT interval V2 or V3 (ms) & $383 \pm 38$ & $370 \pm 35$ & $367 \pm 37$ & 0.001 \\
\hline Fridericia c-QT DII or V5 (ms) & $405 \pm 20$ & $405 \pm 27$ & $394 \pm 31$ & 0.9 \\
\hline Fridericia c-QT V2 or V3 (ms) & $403 \pm 35$ & $405 \pm 37$ & $396 \pm 24$ & 0.6 \\
\hline Framingham c-QT DII or V5 (ms) & $405 \pm 20$ & $405 \pm 27$ & $394 \pm 28$ & 0.6 \\
\hline Framingham c-QT V2 or V3 (ms) & $404 \pm 33$ & $404 \pm 31$ & $396 \pm 24$ & 0.8 \\
\hline $\mathrm{T}_{\text {peak }}-\mathrm{T}_{\text {end }} \mathrm{DIl}$ or V5 (ms) & $88 \pm 9$ & $85 \pm 10$ & $82 \pm 12$ & 0.007 \\
\hline $\mathrm{T}_{\text {peak }}-\mathrm{T}_{\text {end }} \mathrm{V} 2$ or $\mathrm{V} 3(\mathrm{~ms})$ & $103 \pm 14$ & $97 \pm 14$ & $95 \pm 12$ & 0.000 \\
\hline $\mathrm{T}_{\text {peak }}-\mathrm{T}_{\text {end }} / \mathrm{QT} \mathrm{V} 2$ or $\mathrm{V} 3$ ratio & $0.26 \pm 0.03$ & $0.26 \pm 0.07$ & $0.25 \pm 0.03$ & 0.8 \\
\hline $\mathrm{T}_{\text {peak }}-\mathrm{T}_{\text {end }} / \mathrm{QT}$ DIl or V5 ratio & $0.22 \pm 0.02$ & $0.23 \pm 0.02$ & $0.22 \pm 0.02$ & 0.4 \\
\hline
\end{tabular}

Note: aP value calculated between ERP group and control group.

Abbreviations: BP, blood pressure; c-QT, corrected QT interval; ECG, electrocardiogram; ERP, early repolarization pattern. 
QT intervals, corrected QT intervals, $\mathrm{T}_{\text {peak }}-\mathrm{T}_{\text {end }}$ intervals and $\mathrm{T}_{\text {peak }}-\mathrm{T}_{\text {end }} / \mathrm{QT}$ ratio in Brugada-type ECG pattern group were not statistically different among control athletes.

\section{Prevalence of early ventricular repolarization pattern}

A total of 119 ECGs (22\%) were found to fulfill the criteria for ERP that was obtained in 98 males and in 21 females. Males are more prevalent in ERP than in control group (82.3\% versus $58.9 \% ; P<0.0001)$.
ERP was present in the inferior leads (II, III, aVF) in 37 patients $(31.1 \%)$, in the lateral leads ( $\mathrm{I}, \mathrm{aVL}, \mathrm{V}_{4}-\mathrm{V}_{6}$ ) in 71 patients $(59.6 \%)$, and in both the inferior and lateral leads in 11 patients (9.2\%) (Figures $2 \mathrm{~A}$ and $2 \mathrm{~B}$ ).

Weight and body area were significant, although only marginally higher in ERP athletes than in controls. Mean age, mean height, and systolic and diastolic blood pressure were similar between the two groups.

PR interval, $\mathrm{P}$ wave duration and amplitude, QRS, $\mathrm{P}$ wave, and $\mathrm{T}$ wave axis were similar between ERP group
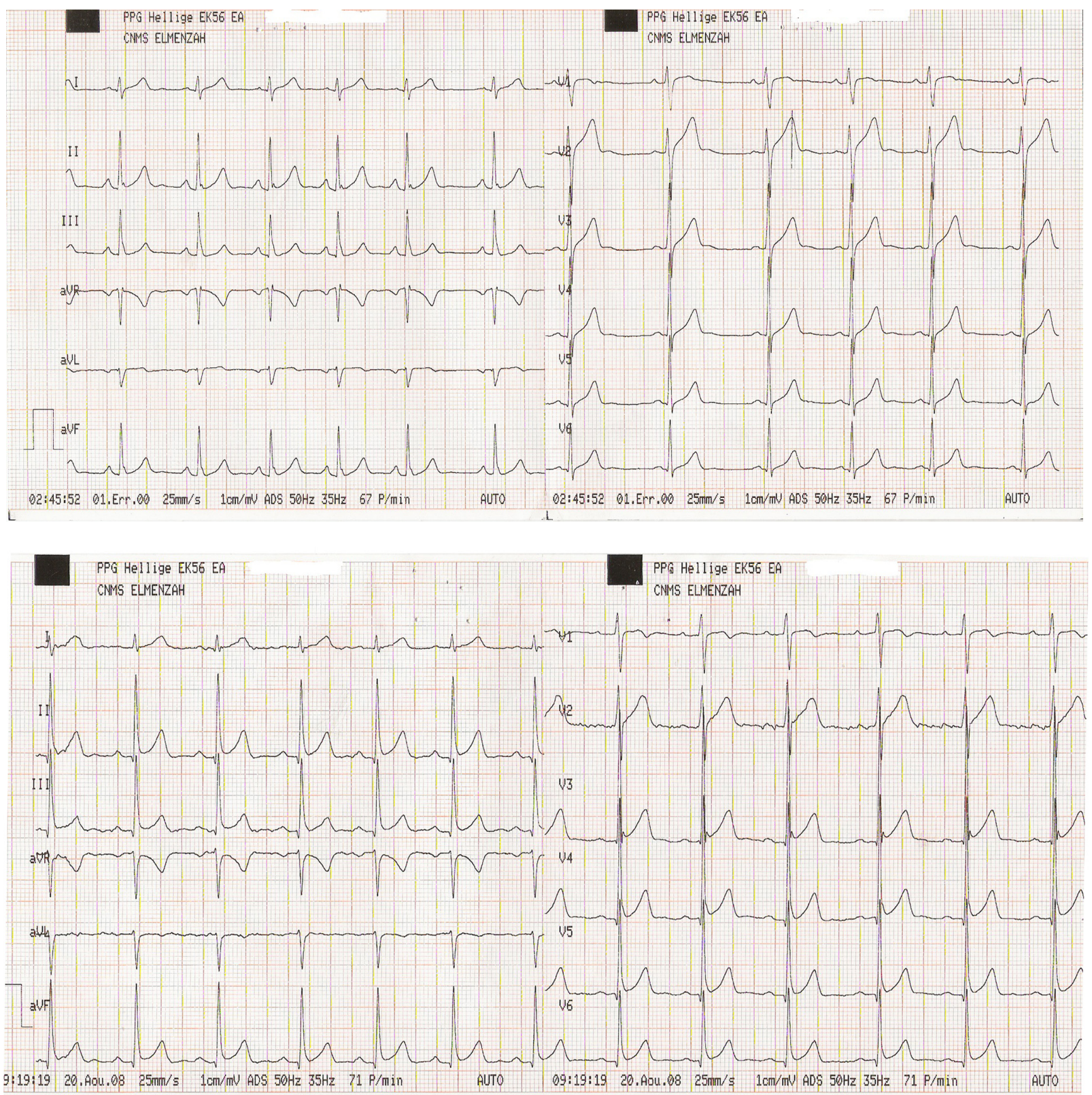

Figure 2 Sample electrocardiograms from two athletes, demonstrating early ventricular repolarization (ERP)-type ECG. ERP defined as $\geq \mathrm{I}$ mm elevation of the QRS-ST junction (J point) in either inferior leads (Type 2) (A) or inferior and lateral leads (Type 3) (B). 
and controls. ERP athletes had lower heart rate, greater QRS and T wave amplitude, and a slightly but significantly shorter QRS duration than the controls.

The duration of the QT interval was longer in ERP athletes than in control athletes, but no difference was observed when the QT interval was corrected for heart rate (Table 1). $\mathrm{T}_{\text {peak }}-\mathrm{T}_{\text {end }}$ intervals were longer in the ERP athletes than in control athletes. However, $\mathrm{T}_{\text {peak }}-\mathrm{T}_{\text {end }} / \mathrm{QT}$ ratio was not different between the two groups (Table 1).

\section{Discussion}

The frequency of Brugada-type ECG pattern and ERP were found to differ among ethnic groups. No data regarding the frequency of the $\mathrm{J}$ wave sign exist in North African populations.

\section{Brugada-type ECG pattern}

Our results indicate that the frequency of the Brugada-type ECG pattern was $1.66 \%$ in athletes, with a saddlebacktype ECG abnormality in all cases. Epidemiological data suggest that Brugada-type ECG pattern is ubiquitous, but it varies significantly among ethnic populations, higher in south-eastern Asian countries, an event possibly reflecting the geographical genetic distribution of the disease. ${ }^{6,10}$ Large epidemiological information has been reported from Asian, ${ }^{11-21}$ European, ${ }^{22-30}$ and American ${ }^{31-34}$ populations, and the data available are difficult to compare because of differences in the diagnostic criteria applied, and differences in the characteristics of the populations selected (sex ratio, age, healthy subjects or tertiary hospital patients) (Table 2).

In accordance with different studies, ${ }^{23,25,30}$ we did not document any person with Brugada Type 1 ECG pattern.

Considering the dynamic nature of the ECG features, the true incidence of Brugada-type ECG pattern might have been underestimated. ${ }^{29}$

Only one previous study had evaluated the prevalence of Brugada-type ECG pattern in an athletic cohort of 155 males with a reported prevalence of $7.7 \%$, with a Brugada Type 1 ECG pattern in all cases. ${ }^{24}$

The disparities between the present study and the Bianco et al study ${ }^{24}$ may be explained by differences between the two study populations. Bianco et al have included only males, older (mean age of the population: $30.9 \pm 10.1$ years), and competitive athletes. ${ }^{24}$

In southern Europe, Hermida et $\mathrm{al}^{22}$ found a high prevalence of concave ST-segment elevation in 1000 European men $(6 \%)$ and a far lower prevalence of convex ST-segment elevation $(0.1 \%)$. Monroe and $\operatorname{Littman}^{31}$ found 52 cases of the Brugada-type ECG among approximately 12,000 unselected noncardiac hospitalized patients. In their report, the convex pattern was present in only two cases. In adolescents and in school children, the frequency of Brugada-type ECG pattern was very low even in regions of Southeast Asia where the Brugada syndrome is endemic. ${ }^{14-16}$ Yamakawa et al ${ }^{14}$ have demonstrated a tendency for the prevalence of Brugada-type ECG pattern to increase with age. In the present study, we did not evaluate the prognostic value of Brugada type ECG pattern. Previous studies have suggested that Brugada-type ECG pattern has a benign natural course, independent of the ethnic origin of the study population. ${ }^{12,20,21,28,29}$

\section{ERP}

Of our healthy "young athletes", 22\% had J-point elevation, a figure consistent with the $22 \%{ }^{35}$ to $27 \%{ }^{37}$ of young athletes with J-point elevation reported by others. ${ }^{35-37}$ Bianco et $\mathrm{al}^{24}$ identified a higher ERP prevalence (89\%) in their competitive athlete group (age $30.9 \pm 10.1$ years). The athletes included in our study and those described by Rosso et $\mathrm{al}^{35}$ were noncompetitive.

The ERP has long been considered to be a "benign" ECG manifestation that is seen more commonly in young healthy men and athletes. ${ }^{37-40}$ No athletes with ERP, reported by Bianco et $\mathrm{al}^{24}$ had suffered from major ventricular arrhythmias from the time of the study (2001) onward to 2009. ${ }^{40}$ However, mounting evidence suggests that the ERP may be associated with a risk for ventricular fibrillation, depending on the location of ERP, magnitude of the J wave, and degree of ST elevation. ${ }^{3-5,41,42}$

Recently, Sinner et $\mathrm{al}^{42}$ have reported a high prevalence of ERP (13.1\%) in a population-based cohort of middleaged individuals (35-74 years). After a mean follow-up of 18.9 years, ERP was associated with about a 2-4-fold increased risk of cardiac mortality in individuals between 35 and 54 years. An inferior localization of ERP was associated with a particularly increased risk. ${ }^{42}$

Heart rate was found to be lower in ERP subjects than in controls, as previously reported. ${ }^{24,37,43,44}$ A greater vagotonia in ERP subjects has been previously reported as a possible contributing factor. ${ }^{37,43}$ The distribution of J-point elevation in our study was similar to that described by Rosso et al. ${ }^{35}$ Athletes had more commonly J-point elevation in lateral leads (V4-V6, Type 1) than in the inferior leads (Type 2).

The QRS duration was significantly shorter in ERP athletes than in controls. This is in accordance with previ- 


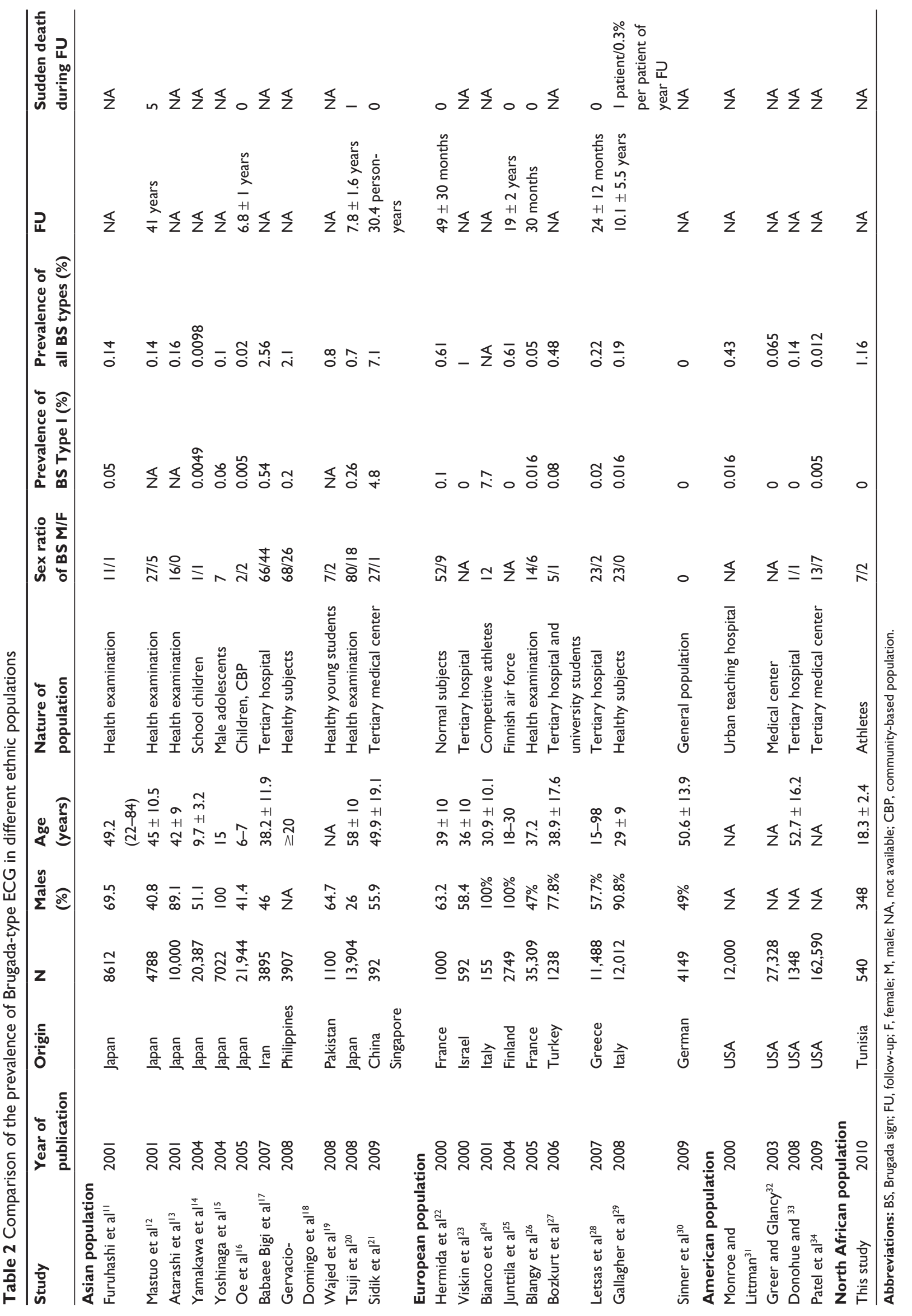


ously published data, ${ }^{24}$ but discordant with the Dilaveris et al study. ${ }^{44}$ Disparities may be explained by differences in the populations studied and possible differences in the level of physical conditioning.

In accordance with previous publications, mean QT duration was significantly higher in ERP athletes than in control athletes..$^{24,37,44}$ However, corrected QT intervals were similar between these two groups, which is in accordance with the Mehta and Jain study ${ }^{37}$ but in contrast with other studies finding lower corrected QT in ERP subjects than in controls. ${ }^{44} \mathrm{~T}_{\text {peak }}-\mathrm{T}_{\text {end }}$ intervals were significantly higher in ERP than in control athletes. $\mathrm{T}_{\text {peak }}-\mathrm{T}_{\text {end }} / \mathrm{QT}$ ratio showed no difference between these two groups.

\section{Study limitations}

First, considering the dynamic nature of the ECG features, the true prevalence of Brugada-type ECG pattern and ERP might have been underestimated in this study. Second, we have identified differences in QT duration on leads V2 and II, which may be explained by differences in the projection of the T-wave loop between the ECG leads, or may simply be due to inaccuracies in defining the end of the $\mathrm{T}$ wave. Third, the physical activity level depending on the corresponding disciplines was not evaluated. Therefore, possible association between the presence of ERP and the athlete discipline was not investigated. Finally, no follow-up was described to ERP and Brugada-type ECG pattern, so no prognostic value of these ECG patterns were available.

\section{Conclusion}

The results indicate that the frequency of the Brugada-type ECG pattern and ERP were respectively $1.66 \%$ and $22 \%$ in athletes, being more prevalent in males. These results are similar to the findings of studies performed in European and American countries. ERP was associated with shorter QRS duration and longer $\mathrm{T}_{\text {peak }}-\mathrm{T}_{\text {end }}$ interval. Further populationbased investigation is warranted to determine the prognostic value of the J-point elevation.

\section{Disclosure}

The authors report no conflicts of interest in this work.

\section{References}

1. Brugada P, Brugada J. Right bundle branch block, persistent ST segment elevation and sudden cardiac death: a distinct clinical and electrocardiographic syndrome. A multicenter report. J Am Coll Cardiol. 1992; 20(6):1391-1396.

2. Brugada J, Brugada R, Brugada P. Right bundle-branch block and ST segment elevation in leads V1 through V3: a marker for sudden death in patients without demonstrable structural heart disease. Circulation. 1998;97(5):457-460.
3. Haissaguerre M, Derval N, Sacher F, et al. Sudden cardiac arrest associated with early repolarization. $N$ Engl J Med. 2008;358(19):2016-2023.

4. Nam GB, Kim YH, Antzelevitch C. Augmentation of J waves and electrical storms in patients with early repolarization. $N$ Engl J Med. 2008;358(19):2078-2079.

5. Tikkanen JT, Anttonen O, Junttila MJ, et al. Long-term outcome associated with early repolarization on electrocardiography. $N$ Engl J Med. 2009;361(26):2529-2537.

6. Antzelevitch C, Brugada P, Borggrefe M, et al. Brugada syndrome: report of the second consensus conference. Heart Rhythm. 2005; 2(4):429-440.

7. Wilde AA, Antzelevitch C, Borggrefe, et al. Proposed diagnostic criteria for the Brugada syndrome: consensus report. Circulation. 2002;106(19):2514-2519.

8. Fridericia LS. Die systolenduer im elektrokardiogramm bei normalen menschen und bei herzkranken. Acta Med Scand. 1920;53:469-486.

9. Sagie A, Larson MG, Goldberg RJ, Bengtson JR, Levy D. An improved method for the adjusting the QT interval for heart rate (The Framigham Heart Study). Am J Cardiol. 1992;70(7):797-801.

10. Benito B, Brugada J, Brugada P. Brugada syndrome. Prog Cardiovasc Dis. 2008;51(1):1-22.

11. Furuhashi M, Uno K, Tsuchihashi K, et al. Prevalence of asymptomatic ST segment elevation in right precordial leads with right bundle branch block (Brugada-type ST shift) among the general Japanese population. Heart. 2001;86(2):161-166.

12. Matsuo K, Akahoshi M, Nakashima E, et al. The prevalence, incidence and prognostic value of the Brugada type electrocardiogram: a population-based study of four decades. $J$ Am Coll Cardiol. 2001; 38(3):765-770.

13. Atarashi $\mathrm{H}$, Ogawa $\mathrm{S}$, Harumi $\mathrm{K}$, et al; for the Idiopathic Ventricular Fibrillation Investigators. Three-year follow-up of patients with right bundle branch block and ST segment elevation in the right precordial leads: Japanese Registry of Brugada Syndrome. Idiopathic Ventricular Fibrillation Investigators. J Am Coll Cardiol. 2001;37(7):1916-1920.

14. Yamakawa Y, Ishikawa T, Uchino K, et al. Prevalence of right bundle-branch block and right precordial ST-segment elevation (Brugada-type electrocardiogram) in Japanese children. Circ J. 2004; 68(4):275-279.

15. Yoshinaga M, Anan R, Nomura Y, et al. Prevalence and time of appearance of Brugada electrocardiographic pattern in young male adolescents from a three-year follow-up study. Am J Cardiol. 2004; 94(9):1186-1189.

16. Oe H, Takagi M, Tanaka A, et al. Prevalence and clinical course of the juveniles with Brugada-type ECG in Japanese population. Pacing Clin Electrophysiol. 2005;28(6):549-554.

17. Babaee Bigi MA, Aslani A, Shahrzad S. Prevalence of Brugada sign in patients presenting with palpitation in southern Iran. Europace. 2007; 9(4):252-255.

18. Gervacio-Domingo G, Isidro J, Tirona J, et al. The Brugada type 1 electrocardiographic pattern is common among Filipinos. $J$ Clin Epidemiol. 2008;61(10):1067-1072.

19. Wajed A, Aslam Z, Abbas SF, et al. Frequency of Brugada-type ECG pattern (Brugada sign) in an apparently healthy young population. J Ayub Med Coll Abbottabad. 2008;20(3):121-124.

20. Tsuji H, Salto T, Morisaki K, Iwasaka T. Prognosis of subjects with Brugada-type electrocardiogram in a population of middle-aged Japanese diagnosed during a health examination. Am J Cardiol. 2008; 102(5):584-587.

21. Sidik NP, Quay CN, Loh FC, Chen LY. Prevalence of Brugada sign and syndrome in patients presenting with arrhythmic symptoms at a Heart Rhythm Clinic in Singapore. Europace. 2009;11(5):650-656.

22. Hermida JS, Lemoine JL, Aoun FB, Jarry G, Rey JL, Quiret JC. Prevalence of the Brugada syndrome in apparently healthy population. Am J Cardiol. 2000;86(1):91-94.

23. Viskin S, Fish R, Eldar M, et al. Prevalence of the Brugada sign in idiopathic ventricular fibrillation and healthy controls. Heart. 2000; 84(1):31-36. 
24. Bianco M, Bria S, Gianfelici A, Sanna N, Palmieri V, Zeppilli P. Does early repolarization in the athlete have analogies with the Brugada syndrome? Eur Heart J. 2001;22(6):504-510.

25. Junttila MJ, Raatikainen MJ, Karjalainen J, Kauma H, Kesaniemi YA, Huikuri HV. Prevalence and prognosis of subjects with Brugada-type ECG pattern in a young and middle aged Finnish population. Eur Heart J. 2004;25(10):874-878.

26. Blangy H, Sadoul N, Coutelour JM, et al. Prevalence of Brugada syndrome among 35309 inhabitants of Lorraine screened at a preventive medicine centre. Arch Mal Coeur Vaiss. 2005;98(3):175-180.

27. Bozkurt A, Yas D, Seydaoglu G, Acarturk E. Frequency of Brugadatype ECG pattern (Brugada sign) in southern Turkey. Int Heart J. 2006; 47(4):541-547.

28. Letsas K, Gavrielatos G, Efremidis M, et al. Prevalence of Brugada sign in a Greek tertiary hospital population. Europace. 2007;9(11): 1077-1080.

29. Gallagher MM, Forleo GB, Behr ER, et al. Prevalence and significance of Brugada-type ECG in 12,012 apparently healthy European subjects. Int $J$ Cardiol. 2008;130(1):44-48.

30. Sinner MF, Pfeufer A, Perz S, et al. Spontaneous Brugada electrocardiogram patterns are rare in the German general population: results from the KORA study. Europace. 2009;11(10):1338-1344.

31. Monroe MH, Littman L. Two-year case collection of the Brugada syndrome electrocardiogram pattern at a large teaching hospital. Clin Cardiol. 2000;23(11):849-851.

32. Greer RW, Glancy DL. Prevalence of the Brugada electrocardiographic pattern at the Medical Center of Louisiana in New Orleans. J La State Med Soc. 2003;155(5):242-246.

33. Donohue D, Tehrani F, Jamehdor R, Lam C, Movahed MR. The prevalence of Brugada ECG in adult patients in a large university hospital in the western United States. Am Heart Hosp J. 2008;6(1):48-50.

34. Patel SS, Anees S, Ferrick KJ. Prevalence of a Brugada pattern electrocardiogram in an urban population in the United States. Pacing Clin Electrophysiol. 2009;32(6):704-708.
35. Rosso R, Kogan E, Belhassen B, et al. J-point elevation in survivors of primary ventricular fibrillation and matched control subjects. $\mathrm{J} \mathrm{Am}$ Coll Cardiol. 2008;52(15):1231-1238.

36. Gussak I, Antzelevitch C. Early repolarization syndrome: clinical characteristics and possible cellular and ionic mechanisms. J Electrocardiol. 2000;33(4):299-309.

37. Mehta MC, Jain AC. Early repolarization on scalar electrocardiogram. Am J Med Sci. 1995;309(6):305-311.

38. Wasserburger RH, Alt WJ. The normal RS-T segment elevation variant. Am J Cardiol. 1961;8:184-192.

39. Yan GX, Lankipalli RS, Burke JF, Musco S, Kowey PR. Ventricular repolarization components on the electrocardiogram: cellular basis and clinical significance. J Am Coll Cardiol. 2003;42(3):401-409.

40. Bianco M, Zeppilli P. Early repolarization in the athletes. J Am Coll Cardiol. 2009;53:2200.

41. Kalla H, Yan GX, Marinchak R. Ventricular fibrillation in a patient with prominent J (Osborn) waves and ST segment elevation in the inferior electrocardiographic leads: a Brugada syndrome variant? J Cardiovasc Electrophysiol. 2000;11(1):95-98.

42. Sinner MF, Reinhard W, Müller M, et al. Association of early repolarization pattern on ECG with risk of cardiac and all-cause mortality: a population-based prospective cohort study (MONICA/KORA). PLoS Med. 2010;7(7):e1000314.

43. Haydar ZR, Brantley DA, Gittings NS, Wright JG, Fleg JL. Early repolarization: an electrocardiographic predictor of enhanced aerobic fitness. Am J Cardiol. 2000;85(2):264-266.

44. Dilaveris P, Pantazis A, Gialafos E, Gialafos J, Toutouzas P, Stefanadis C. Assessment of ventricular repolarization alterations in subjects with early repolarization. Int J Cardiol. 2004;96(2):273-279.
Open Access Journal of Sports Medicine

\section{Publish your work in this journal}

Open Access Journal of Sports Medicine is an international, peer-reviewed, open access journal publishing original research, reports, reviews and commentaries on all areas of sports medicine. The manuscript management system is completely online and includes a very quick and fair peer-review system.

\section{Dovepress}

Visit http://www.dovepress.com/testimonials.php to read real quotes from published authors. 